\title{
IMPLEMENTASI PERILAKU HIDUP SEHAT SISWA SD NEGERI GUGUS IV KECAMATAN KOTO XI TARUSAN KABUPATEN PESISIR SELATAN
}

\author{
Oleh \\ Rosmaneli \\ Jurusan Pendidikan Olahraga, Fakultas IImu Keolahragaan \\ Universitas Negeri Padang
}

\begin{abstract}
Abstrak; Latar belakang masalah penelitian ini adalah kurang optimalnya kondisi kesehatan siswa SD Negeri Gugus IV Kecamatan Koto XI Tarusan yang diduga karena kurangnya pengamalan perilaku hidup sehat dalam kehidupan seharihari. Tujuan penelitian ini untuk mendeskripsikan perilaku hidup sehat siswa dalam aspek: kebersihan pribadi, kebiasaan makan, kebiasaan bermain, dan pengaturan waktu istirahat.Untuk mencapai tujuan di atas, digunakan jenis penelitian deskriptif. Populasi penelitian adalah semua siswa SD Negeri di Gugus IV Kecamatan Koto XI Tarusan yang berjumlah 1044 orang. Sampel penelitian hanya siswa kelas $\mathrm{V}$ saja dengan jumlah 178 orang yang ditetapkan dengan teknik purposive sampling, instrumen yang digunakan adalah kuesioner. Teknik analisis data dilakukan dengan perhitungan frekwensi dan persentase.

Hasil penelitian adalah: (1) Perilaku hidup siswa SD Negeri Gugus IV Kecamatan Koto XI Tarusan secara keseluruhan atau tidak membedakan indikator yang diteliti hanya mencapai kategori baik; (2) Perilaku hidup sehat siswa untuk masing-masing indikator: (a) kebersihan pribadi dengan kategori baik; (b) Kebiasaan makan, baik; (c) Kebiasaan bermain, sangat baik; (d) Pengaturan waktu istirahat, baik; dan (3) Perilaku hidup sehat untuk masing-masing sekolah:

(a) SD Negeri 03 Simpang, baik; (b) SD Negeri 28 Simpang, baik; (c) SD Negeri 06 Kampung Pansur, sangat baik; (d) SD Negeri 18 Kampung Pansur, baik; (e) SD Negeri 39 Kampung Pansur, baik; (f) SD Negeri 16 Pulau Karam, baik; (g) SD Negeri 45 Pulau Karam, baik; (h) SD Negeri 15 Sunyai Nyalo, baik; dan (i) SD Negeri 25 Carocok, baik.

Kata Kunci: Perilaku Hidup sehat
\end{abstract}

\section{PENDAHULUAN}

Sehat merupakan landasan dasar yang harus diupayakan terlebih dahulu untuk menciptakan sumber daya manusia yang berkualitas. Tanpa kondisi kondisi kesehatan yang baik, berbagai keberhasilan hidup, baik untuk diri sendiri, orang lain, bangsa dan negara tentu tidak akan dapat dicapai. Oleh karena itu, kesadaran kemampuan dan kemauan untuk berperilaku hidup sehat bagi setiaporang harus diupayakan terlebih dahulu.

Untuk membudayakan perilaku hidup sehat bagi anak-anak sejak usia dini, maka di Sekolah Dasar (SD) dilaksanakan pembelajaran 
Penjasorkes. Kondisi ideal yang diharapkan ditampilkan siswa adalah tingginya kemauan mereka untuk menjaga kesehatan dan mencegah penyakit. Jika perilaku hidup sehat ini telah dilaksanakan secara baik, tentu mereka dapat memiliki kondisi kesehatan yang optimal.

Realitas atau kenyataan yang teramati, masih banyak diantara siswa SD Negeri Gugus IV Kecamatan Koto XI Tarusan Pesisir Selatan yang belum memiliki kondisi kesehatan yang baik. Oleh karena itu mereka rentan terhadap serangan penyakit. Data pada buku absensi menunjukkan bahwa sebagian besar alasan siswa berhalangan hadir di sekolah adalah karena sakit.

Hasil studi pendahuluan menunjukkan bahwa dari beberapa faktor penyebab kurang optimalnya kondisi kesehatan siswa SD Negeri Gugus IV Kecamatan Koto XI Tarusan. Faktor yang diduga lebih dominan adalah karena kurangnya pengamalan perilaku hidup sehat. Oleh karena itu penting dilakukan penelitian untuk mengungkapkan implementasi perilaku hidup sehati siswa SD Negeri Gugus IV Kecamatan Koto XI Tarusan Kabupaten Pesisir Selatan.

Sesuai masalah di atas, maka tujuan penelitian ini untuk mendeskripsikan perilaku hidup sehat siswa SD Negeri Gugus IV Kecamatan Koto XI Tarusan Kabupaten Pesisir Selatan tentang aspek: kebersihan pribadi, kebiasaan makan, kebiasaan bermain, dan pengaturan waktu istirahat.
Sebelum dikemukakan kajian
teori perilaku hidup sehat tentang

kebersihan pribadi, kebiasaan makan, dan pengaturan waktu istirahat, terlebih dahulu akan diungkapkan pengertian perilaku hidup sehat itu sendiri.

Istilah perilaku hidup sehat dilihat dari aspek bahasa terdiri dari tiga suku kata yaitu : perilaku, hidup, dan sehat. Depdibud (2005: 671, 306 dan 749) mengemukakan arti ketiga suku kata tersebut yaitu :

(1) Perilaku adalah tanggapan atau reaksi individu yang terwujud dalam gerakan (sikap), badan atau ucapan

(2) Hidup adalahmasih terus ada, bergerak, bekerja sebagaimana mestinya (tentang : manusia, binatang, tumbuhan, dsb).

(3) Sehat adalah keadaan baik segenap bahan serta bagian bagiannya (bebas dari penyakit).

Dengan merangkum ketiga suku kata dalam kutipan di atas, dapat diungkapkan bahwa perilaku hidup sehat adalah reaksi seseorang dalam sikapnya (baik perbuatan maupn ucapan) untuk memelihara dirinya agar bebas dari penyakit sehingga dapat melakukan berbagai kegiatan sebagaimana mestinya.

Pengertian di atas sesuai dengan yang dikemukakan Depkes RI (2005:5) berikut : "Perilaku hidup sehat adalah sikap atau tindakan proaktif untuk memelihara dan mencegah terjadinya resiko penyakit, melindungi diri dari ancaman penyakit, serta 
berperan aktif dalam gerakan kesehatan masyarakat".

1. Perilaku Hidup Sehat tentang Kebersihan Pribadi

a. Kebersihan Kuku

$\mathrm{Di}$ bagian ujung-ujung jari tangan dan jari-jari kaki kita terdapat semacam zat tanduk yang disebut dengan kuku. Kuku-kuku pada jari tangan dan kaki kita itu mengalami pertumbuhan sehingga bertambah panjang. Pada kuku jari tangan yang panjang, mudah lengket berbagai kotoran. Oleh karena itu, pada kuku jari tangan yang panjang tampak berwarna kehitaman yang berbentuk dari daki yang menumpuk.

Kotoran atau daki yang menumpuk di bawah kuku jari tangan yang panjang-panjang itu adalah sumber penyakit, karena penuh dengan kuman dan kotoran. Pada waktu makan, kuman atau kotoran yang menumpuk di bawah kuku jari tangan itu dapat tertelan bersama makanan. Akibatnya, kita mengalami sakit seperti disentri.

Melalui uraian ringkas diatas, diperoleh gambaran bahwa seseorang siswa SD yang memelihara kebersihan kuku akan mengamalkan perilaku hidup sehat berikut : (1) mampu memotong kuku sendiri; (2) memotong kuku jari sehingga tidak lagi mengandung kotoran; dan (3) memotong kuku secara rutin minimal sekali dalam satuminggu.

b. Kebersihan Rambut

Kesehatan rambut akan terganggu jika kulit kepala tidak bersih, misalnya kulit kepala yang berketombe. Depdikbud (2005:435) mengemukakan: "Ketombe (dalam bahasa Latihn disebut Tinea kufuracea) adalah penyakit kulit kepala (bersisik-sisik putih dan gatal) disebut juga dengan istilah kelemumur". Seseorang yang memiliki kulit kepala berketombe akan merasakan semakin gatal-gatal. Pada saat digarut atau disisir, sisik-sisik putih atau ketombe di kulit kepala itu akan mengelupas dan lengket pada rambut. Ketombe akan mengganggu kesehatan rambut.

Senada dengan uraian di atas, Rositawaty dan Aris Muharam (2008:19) menjelaskan bahwa: "Rambut yang sehat terlihat rapi dan bersih. Rambut yang sehat tidak bau. Cucilah rambut agar sehat. Mencuci rambut dua kali dalam satu minggu. Kamu harus mencuci rambut dengan sampo".

Berdasakran uraian di atas dapat digambarkan bahwa seseorang yang berpelaku hidup sehat tentang kebersihan rambut akan melaksanakan: (1) mencuci rambut dua kali dalam seminggu, (2) mencuci rambut dengan sampo; dan (3) selalu memelihara kerapian rambut.

c. Kebersihan Kulit, Tangan dan Kaki

Permukaan tubuh kita dilapisi oleh kulit. Pada kulit kita terdapat lobang-lobang yang sangat halus yang disebut pori-pori. Pori-pori merupakan saluran pembuangan keringat. Pada saat berolahraga atau melakukan aktivitas fisik, tubuh kita menjadi panas dan pori-pori kita mengeluarkan keringat. Jika keringat tidak dibersihkan akan membentuk daki atau kotoran. Kulit berdaki adalah kulit yang kotor. 
Kulit di bagian tangan dan kaki adalah yang paling mudah dihinggapi kotoran. Oleh sebab itu, kaki dan tangan harus dibersihkan sebelum tidur. Kotoran-kotoran. Oleh sebab itu, kaki dan tangan harus dibersihkan sebelum tidur. Kotoran pada kaki dan tangan dapat mengotori alas tidur dan bantal.

Berdasarkan uraian di atas, seseorang yang memelihara kebersihan kulit, tangan dan kaki akan menampilkan perilaku hidup sehat berikut : (1) mencuci tangan sebelum makan ; (2)mencuci tangan dan kaki sebelum tidur ; (3) mandi dua kali sehari; dan (4) mandi dengan sabun mandi.

\section{d. Kebersihan Gigi}

Gigi berguna untuk menguyah makanan. Sisa-sisa makanan dapat lengket di permukaan gigi. Coklat, susu, dan makanan yang terbuat dari beras ketan (pulut) seperti onde-onde dan lupis merupakan conohmakanan yang sangat mudah lengket di permukaan dan di sela-sela gigi. Sisasisa makanan itu akan bertumpuk dan mengeras di permukaan gigi membentuk plak. Persatuan Dokter Gigi Indonesia (PDG, 2009:1) mengemukakan, "Plak adalah lapisan kuman dan sisa makanan yang melekat erat pada permukaan gigi yang menyebabkan gigi berlubang".

Sejalan dengan maksud kutipan diatas, PDGI (2009:1) mengemukakan tips (cara) merawat gigi agar tetap sehat sebagai berikut :

(1) Sikatlah gigi secara teratur paling sedikit $2 x$ sehari, pagi setelah makan/sarapan dan malam hari sebelum tidur;

(2) Gunakanlah pasta gigi yang mengandung fluorider;

(3) Makan makanan bergizi dan kurangi makan manis dan mudah lengket

(4) Periksalah gigi ke dokter setiap 6 bulan sekali.;

(5) Jangalah bertukar sikat gigi dengan orang lain agar tidak terjadi penularan penyakit

Sesuai kutipan di atas dapat dijelaskan bahwa cara perawatan gigi agar tetap dalam kondisi sehat dilakukan dengan menyikat gigi secara teratur, paling sedikit $2 \times$ dalam satu hari yakni pagi hari sehabis makan dan malam hari sebelum tidur, untuk menyikat gigi digunakan pasta gigi yang mengandung fluorida yaitu bahan untuk membersihkan dan menguatkan gigi, mengurangi makanan yang manis-manis dan mudah lengket, membiasakan diri untuk memeriksakan kesehatan gigi setiap 6 bulan sekali, dan tidak menggunakan sikat gigi orang lain atau meminjamkan sikat gigi sendiri kepada orang lain, agar tidak terjadi penularan penyakit.

Berdasarkan uraian di atas dapat dikemukakan bahwa seseorang yang memelihara kebersihan gigi akan menampilkan perilaku hidup sehat seperti : (1) menyikat gigi sehabis makan; (2) menyikat gigi sebelum tidur; (3) menyikat gigi dengan odol; (4) mengurangi memakan makanan yang manis-manis; (5) mengurangi makanan makanan yang mudah lengket pada gigi; (6) tidak menggunakan sikat gigi orang lain; (7) memeriksakan 
kesehataen gigi sekali enam bulan ke dokter/puskesmas.

e. Kebersihan Hidung

Hidung merupakan indera pembau dan sekaligus bagian dari sistem pernafasan. Agar dapat berfungsi secara optimal, hidung perlu dijaga kebersihannya. Haryanto (1999;79) mengemukakan sebagai berikut :Secara garis, alat-alat pernafasan kita terdiri dari lubang hidung, batang tenggorokan, dan paruparu. Lubang hidung berfungsi sebagai lalu lintas jalan keluar masuk udara. Di dalam lubang hidung terdapat bulubulu halus yang berguna untuk menyaring udara kotor. Selain itu, hidung juga berguna untuk mengatur suhu udara yang akan masuk ke paruparu.

Sesuai maksud kutipan di atas, dapat dikemukakan bahwa hidung merupakan organ penting, baik sebagai bagian dari sistem pernafasan maupun sebagai indera pembau. Agar dapat berfungsi optimal lubang hidung harus diupayakan agar tetap bersih. Bulu-bulu yang terdapat di dalam lubang hidung selalu dalam keadaan basah, agar udara kotor atau debu diserap/lengket pada bulu-bulu tersebut.

Berpedoman pada uraian di atas, dapat dikemukakan bahwa seseorang yang memelihara kebersihan hidup akan menampilkan perilaku hidup sehat seperti : (1) menutup hidung dan mulut dengan sapu tangan pada saat banyak debu bertebangan di sekitarnya; (2) membersihkan lubang hidung dengan kain yang lembut; (3) segera membersihkan hidung jika ada kotoran/debu.

f. Kebersihan Telinga

Telinga merupakan indera pendengar. Pada permukaan liang telinga terdapat ujung-ujung saraf penangkap bunyi. Agar telinga dapat berfungsi dengan baik perlu dijaga agar tetap bersih. Rositawaty dan Aris Muharam (2008:17) mengemukakan sebagai berikut : Bagaimana cara merawat telinga agar tetap sehat? Kamu harus membersihkan atau mengeringkan permukaan liang telinga setiap selesai mandi. Kamu harus membersihkan liang telinga setiap minggu dengan kapas. Jangan mendengarkan suara yang terlalu keras.

Berdasarkan kutipan di atas, dapat dijelaskan bahwa liang telinga harus dilap atau dikeringkan setiap selesai mandi. Tujuannya agar air tidak masuk ke dalam liang telinga. Membersihkan liang telinga setiap selesai mandi cukup dengan kain lembut (handuk, dan sebagainya) dengan menggunakan ujung jari.

Berpedoman pada uraian di atas, dapat dikatakan bahwa seseorang yang memelihara kebersihan telinga akan menampilkan perilaku hidup sehat seperti : (1) menghindari sumber bunyi yang memekakkan (terlalu keras); (2) mengeringkan liang telinga setiap habis mandi; (3) membersihkan liang telinga dengan kain/bahan yang lembut; dan (4) membersihkan liang telinga tiap minggu.

2. Perilaku hidup sehat tentang Kebiasaan Makan 
Kebiasaan makan seseorang pada umumnya dapat dilihat atas beberapa aspek yaitu sebagai berikut:

a. Mengatur Kebiasaan Jadwal Makan

Kebiasaan jadwal makan yang baik menurut ilmu kesehatan adalah kebiasaan makan secara teratur jadwal atau waktunya. Jadwal makan yang teratur adalah makan tiga kali sehari, yaitu makan pagi, siang, dan malam. Pada umumnya jadwal makan/sarapan pagi dilakukan sekitar pukul 6.30 pagi; makan siang sekitar pukul 14 siang; dan makan malam sekitar pukul 19 malam.

Berdasarkan uraian di atas dapat dikemukakan bahwa bentukbentuk perilaku hidup sehat tentang mengatur kebiasaan jadwal makan adalah: (1) selalu makan/sarapan pagi; (2) selalu makan slang; (3) selalu makan malam; (4) tidak menundanunda jadwal makan.

b. Menghindari Kebiasaan Jajan

$$
\text { Depdikbud }
$$

menjelaskan, "jajan adalah membeli penganan, buah-buahan, dan sebagainya di kedai atau dijajakan orang". Seseorang yang terbiasa jajan akan membiasakan diri untuk membeli penganan (makanan) di kedai, warung, dijajakan orang dan sebagainya. Kebiasaan jajan seringkali menyebabkan seseorang tidak makan secara teratur, karena jajan dapat menunda rasa lapar. Disamping itu, jajan kurang baik dari aspek kesehatan.

Berdasarkan uraian di atas dapat dikemukakan bahwa seseorang yang berperilaku hidup sehat dalam aspek kebiasaan jajan seperti: (1) menghindari jajan di sembarang tempat; (2) tidak jajan makanan yang dihinggapi lalat; (3) tidak jajan makanan yang tidak ditutup atau terkena debu.

c. Kebiasaan Menguyah Makanan

Proses pencernaan dimulai dari dalam mulut. Di dalam mulut makanan harus dikunyah hingga lumat. Seseorang yang makan dengan tergesa-gesa dapat menelan makanan yang belum cukup lumat. Makanan yang masih keras atau belum lumat akan menghambat proses pencernaan berikutnya di dalam lambung.

Dengan uraian ringkas di atas, dapat dikemukakan bahwa seseorang yang berperilaku hidup sehat tentang mengunyah makanan adalah: (1) makan dengantidak tergesa-gesa; (2) sebelum ditelan, makanan dikunyah hingga benar-benar lumat.

3. Perilaku Hidup Sehat tentang Kebiasaan Bermain

Gusril

mengemukakan sebagai berikut:

Dapat dikatakan bahwa

aktivitas bermain merupakan suatu kegiatan yangspontan yang dilakukan anak-anak pada lingkungannya dengan melibatkan imajinasi, penampilan, seluruh perasaan, tangan atau seluruh badan melalui aktivitas fisik.

Berpedoman kepada kutipan di atas, dapat dijelaskan bahwa aktivitas bermain merupakan bagian dari aktivitas fisik. Melalui kebiasaan bermain, anak melakukan kegiatan spontan di lingkungannya dengan 
menggunakan imajinasi, penampilan, seluruh perasaan, tangan dan seluruh badan dengan menggunakan atau melibatkan aktivitas fisik.

Seseorang anak yang memiliki kebiasaan bermain yang baik, akan menampilkan sikap atau perilaku seperti: (a) terlibat dalam setiap permainan dengan teman sebaya di sekitarnya; (b) memiliki waktu untuk melakukan kegiatan bermain tersebut; (c) menunjukkan kegembiraan dalam bermain; (d) berusaha agar lebih unggul dalam bermain; (e) mengeluarkan energi atau mengeluarkan keringat; (f) tidak mengalami keterbatasan fisik untuk melaksanakan aktivitas bermain; (g) tetap mampu melakukan kegiatan pokok (misalnya belajar) setelah bermain. Kebiasaan bermain yang baik tentu akan meningkatkan kesehatan sekaligus mencegah munculnya berbagai penyakit akibat kurang gerak.

4. Perilaku Hidup Sehat tentang

Pengaturan Waktu Istirahat Istirahat menurut Depdikbud (2005:341) dalam "Kamus Besar Bahasa Indonesia" adalah, berhenti sebentar untuk melepaskan lelah". Pengertian tersebut mengartikan istirahat sebagai saat-saat untuk melepaskan lelah hingga tubuh terasa segar atau kuat kembali.

Begitu juga dengan tubuh kita, juga membutuhkan istirahat agar pulih atau segar kembali untuk melakukan kegiatan berikutnya. Dalam kegiatan di sekolah antara kegiatan-kegiatan belajar disediakan waktu untuk istirahat yang biasa disebut dengan istilah "keluar main". Selesai keluar main siswa kembali masuk kelas untuk melakukan kegiatan belajar selanjutnya.

Istirahat yang paling baik menurut ilmu kesehatan adalah tidur yang cukup. Pada waktu tidur tubuh kita beristirahat, dan ketika bangun tubuh terasa segar kembali. Oleh karena itu, untuk menyegarkan tubuh ataumemulihkan kelelahan setelah melakukan berbagai aktivitas seharihari, kita membutuhkan istirahat atau tidur yang cukup. Gie (1984:63) mengemukakan sebagai berikut :

Untuk keperluan tidur yang cukup setiap harinya hendaklah menyediakan waktu selama 8 jam. Bila untuk tidur siang dipergunakan 1 jam, maka malamnya hendaknya tidur 7 jam. Pada umumnya kemampuan atau daya rohani yang paling surut ialah antara pukul 13 sampai 14 siang. Beristirahat pada waktu siang hari sangat baik apabila dilakukan saat daya rohani tidak dapat bekerja dengan giat tersebut.

Berpedoman pada kutipan di atas, dapat dijelaskan bahwa seseorang membutuhkan tidur yang cukup selama 8 jam, yakni tidur siang selama 1 jam dan tidur selama 7 jam atau tidur antara jam 22.00 sampai jam 05.00 pagi. Untuk istirahat atau tidur siang yang paling baik adalah antara jam 13 sampai 14 atau pada saat daya atau kemampuan rohani tidak dapat bekerja dengan baik.

Sesuai uraian di atas, seseorang yang berperilaku hidup sehat tentang pengaturan waktu istirahat akan melakukan kebiasaan: (1) tidur siang 
sepulang sekolah; (2) tidur siang sekitar 1 jam; (3) tidur malam pukul sepuluh dan bangun pagi pukul lima; dan (4) tidak memaksakan diri untuk belajar/bekerja sampai kelelahan.

\section{METODE}

Penelitian ini termasuk pada jenis penelitian deskriptif. Populasi penelitian ini adalah semua siswa SD Negeri di Gugus IV dKecamatan Koto XI Tarusan yang berjumlah 1044 orang. Sampel penelitian hanya melibatkan siswa kelas $\mathrm{V}$ saja sebanyak 178 orang yang ditetapkan dengan teknik purposive sampling.

Teknik pengumpulan data yang digunakan adalah teknik kuesioner (daftar pertanyaan) yang disusun dalam bentuk angket. Teknik analisis data menggunakan perhitungan frekwensi dan persentase.

\section{HASIL DAN PEMBAHASAN}

Berdasarkan deskripsi data yang dikemukakan, diperoleh hasil penelitian bahwa: baik secara umum atau tidak membedakan indikator penelitian, membedakan indikator, maupun untuk masing-masing SD Negeri Gugus IV Kecamatan Koto XI Tarusan, perilaku hidup sehat cenderung mencapai kategori baik.

Hasil penelitian yang mencapai kategori baik tersebut menegaskan kepada semua pihak bahwa secara keseluruhan perilaku hidup sehat siswa SD Negeri Gugus IV Kecamatan Koto XI Tarusan belum mencapai kondisi ideal atau yang paling diharapkan yaitu kategori sangat baik. Walaupun demikian, perilaku hidup sehat yang telah dilakukan selama ini tidak mengecewakan, karena hasil penelitian ini menunjukkan bahwa tidak ada temuan dengan kategori cukup, kurang, dan sangat kurang.

Belum idealnya pengamatan perilaku hidup sehat siswa SD Negeri Gugus IV Kecamatan Koto XI Tarusan Kabupaten Pesisir Selatan, akan tampak jelas jika dilakukan pembahasan terhadap butir angket sebagaimana berikut ini:

Pertama: Dalam hal menyikat gigi sehabis makan dan sebelum tidur, perilaku hidup sehat belum semestinya. Artinya: masih banyak di antara siswa yang belum menyikat gigi sehabis makan dan sebelum tidur.

Menyikat atau menggosok gigi sehabis makan dan sebelum tidur harus dilaksanakan dengan baik. Hal ini sebagaimana ditegaskan oleh Maryunani (2013:38) bahwa, "Menggosok gigi sebaiknya dilakukan segera setelah selesai makan dan pada saat menjelang tidur malam".

Kedua: Tentang kebiasaan siswa memakan makanan yang manismanis dan cokelat atau selai. Hasil penelitian mengindikasikan bahwa siswa belum berusaha untuk tidak memakan makanan yang manis-manis atau makanan yang mudah lengket di permukaan gigi. Makanan yang mudah lengket pada permukaan gigi termasuk makanan yang manis-manis kurang baik untuk kesehatan gigi.

Ketiga:Masih banyak siswa yang belum memeriksakan kesehatan gigi minimal 1 kali dalam enam bulan. Dokter Soerjohardjo dalam Prizal (2010:35) mengemukakan sebagai berikut: 
Periksalah kesehatan gigi $2 x$ dalam setahun, sekalipun tidak merasakan nyeri. Hingga kini, pada umumnya orang baru pergi ke dokter gigi, bila rasa nyeri giginya sudah tidak tertahan lagi dan bila lubang pada gigi sudah besar.

Berdasarkan kutipan di atas, dapat diketahui bahwa gigi harus diperiksakan kesehatannya sekali dalam enam bulan atau 2 kali dalam setahun. Jangan hanya memeriksakan kesehatan gigi atau hanya ke dokter jika telah menderita sakit gigi. Artinya, walaupun gigi tidak sakit, memeriksakan kesehatan gigi ke dokter atau puskesmas harus dilakukan secara berkala satu kali dalam enam bulan.

Keempat:Berkenaan dengan jajan di sembarang tempat, jajan tanpa mengindahkan lalat, kurang memperhatikan faktor bungkusan makanan, dan kadaluarsa.

Temuan penelitian di atas menjelaskan bahwa: (a) siswa masih banyak yang jajan di sembarang tempat; (b) masih banyak jajan pada tempat yang banyak lalat; (c) membeli makanan yang tidak dibungkus dengan baik; dan (d) masih kurang memperhatikan jadwal kadaluarsa makanan. Dari keempat butir tersebut dapat diartikan bahwa siswa belum memperhatikan tentang kebersihan dan kesehatan makanan yang akan dikonsumsinya.

Memperhatikan kebersihan dan kesehatan makanan yang akan dikonsumsinya harus dibiasakan. Tujuannya agar kita mengkonsumsi makanan yang benar-benar bersih dan sehat.

\section{KESIMPULAN}

Berdasarkan hasil analisis data diperoleh kesimpulan penelitian sebagai berikut: 1) Perilaku hidup sehat siswa SD Negeri Gugus IV Kecamatan Koto XI Tarusan Kabupaten Pesisir Selatan secara umum atau tidak membedakan indikator yang diteliti, hanya mencapai kategori baik.2) Perilaku hidup siswa SD Negeri Gugus IV Kecamatan Koto XI Tarusan Kabupaten Pesisir Selatan untuk masing-masing indikator yang diteliti: (1) Kebersihan Pribadi, hanya mencapai kategori baik; (2) Kebiasaan Makan, hanya mencapai kategori baik; (3) Kebiasaan Bermain, mencapai kategori sangat baik; dan (4) Pengaturan Waktu Istirahat, hanya mencapai kategori baik.3) Perilaku hidup sehat untuk masing-masing SD Negeri Gugus IV Kecamatan Koto XI Tarusan Kabupaten Pesisir Selatan adalah: (a) SD Negeri 03 Simpang, kategori baik; (b) SD Negeri 28 Simpang, kategori baik; (c) SD Negeri 06 Kampung Pansur, kategori sangat baik; (d) SD Negeri 18 Kampung Pansur, kategori baik; (e) SD Negeri 39 Kampung Pansur, kategori baik; (f) SD Negeri 16 Pulau Karam, kategori baik; (g) SD Negeri 45 Pulau Karam, kategori baik; (h) SD Negeri 15 Sunyai Nyalo, kategori baik; (i) SD Negeri 25 Carocok, kategori baik.

\section{DAFTAR RUJUKAN}

Depdikbud. (2005). Kamus Besar Bahasa Indonesia. Jakarta: Balai Pustaka. 
Depdikbud. (1996). Memelihara dan Merawat Badan (Modul A35). Jakarta:Diperbanyak

TB. Angkasa.

Depdiknas. (2007). Model Silabus dan Rencana Pelaksanaan Pembelajaran Mata Pelajaran Pendidikan Jasmani Olahraga dan Kesehatan SMP/MTs.Jakarta: Direktorat Jendral Manajemen Pendidikan Dasar dan Menengah Pertama dan Badan Standar Nasional Pendidikan (BNSP).

Depkes RI. (2005). Perilaku Hidup Sehat. Jakarta: Pusat Promosi Kesehatan.

Gie, The Liang. (1984). Cara Belajar Efisien. Yogyakarta: Gadjah Mada University Press.

Haryanto. (1999). Ilmu Pengetahuan Alam Jilid 2 untuk Kelas 4 SD. Jakarta:Erlangga.

Lutan, Rusli., J. Hartoto, dan Tomoliyus. (2001). Pendidikan Kebugaran Jasmani Orientasi
Pembinaan di Sepanjang Hayat. Jakarta: Direktorat Jendral Olahraga.

Maryunani, Anik. (2013). Perilaku Hidup Bersih dan Sehat. Jakarta: CV. Trans Info Media.

PDGI. (2009). "Petunjuk Praktis Pemeliharaan Kesehatan Gigi dan MulutKeluarga". Brosur Kerjasama PDGI-Pepsodent. Jakarta.

Pusat Kurikulum. (2006). Pengembangan Silabus KTSP Penjasorkes untukSD/MI. Jakarta: Diperbanyak BP. Cipta Jaya.

Rositawaty dan Aris Muharam. (2008). Senang Belajar IImu Pengetahuan Alam.Jakarta: Pusat Perbukuan.

Undang-undang RI No. 23 Tahun 1992 Tentang Kesehatan BesertaPenjelasannya.

Yogyakarta: Pustaka Widyatama, Cetakan Kedua, April 2005. 